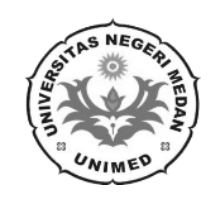

\title{
PENGARUH UKURAN KAP, UKURAN PERUSAHAAN DAN UMUR PERUSAHAAN TERHADAP AUDIT REPORT LAG PADA PERUSAHAAN MANUFAKTUR YANG TERDAFTAR DI BEI TAHUN 2016-2018
}

\author{
Nisha Marina, Nia Ramadhani, Muhammad Ridha Habibi Z. \\ Universitas Negeri Medan
}

\begin{abstract}
ABSTRAK
Ketepatan waktu dalam penyampaian laporan keuangan sangat penting bagi pihak-pihak yang berkepentingan atas laporan keuangan. Ketepatan waktu berarti tersedianya informasi bagi pembuat keputusan pada waktu yang tepat sehingga dapat mempengaruhi keputusan yang akan dibuat. Secara umum, semakin lawas suatu informasi maka semakin kurang berguna informasi tersebut. Ketepatan waktu atas laporan keuangan menjadi sangat penting bagi tiap perusahaan, terutama perusahaan yang terdaftar di Bursa Efek Indonesia. Penelitian ini bertujuan untuk mengetahui pengaruh ukuran KAP, Ukuran Perusahaan dan Umur Perusahaan terhadap Audit Report Lag pada perusahaan Manufaktur yang terdaftar di Bursa Efek Indonesia pada tahun 20162018. Populasi penelitian ini adalah perusahaan manufaktur yang terdaftar di BEI tahun 2016-2018 sebanyak 165 perusahaan. Sampel penelitian sebanyak 189 perusahaan dengan metode purposive sampling, dengan jenis penelitian kuantitatif. Data yang digunakan merupakan data sekunder yaitu laporan keuangan perusahaan yang diperoleh dari www.idx.co.id. Teknik analisis data yang digunakan adalah statistik deskriptif, uji asumsi klasik, analisis regresi berganda, koefisien determinasi, dan uji $t$-statistik. Hasil penelitian secara parsial menunjukkan bahwa ukuran KAP tidak berpengaruh terhadap audit report lag dengan nilai sig 0.646, ini menunjukkan bahwa perusahaan yang diaudit oleh KAP Big Four tidak menjamin bahwa proses audit akan berlangsung cepat. Ukuran perusahaan tidak berpengaruh terhadap audit report lag dengan nilai sig 0.290, ini menunjukkan bahwa besar atau kecilnya perusahaan tidak berpengaruh terhadap panjang atau pendeknya proses penyelesaian audit. Dan umur perusahaan berpengaruh terhadap audit report lag dengan nilai sig 0.005 , ini menunjukkan bahwa bahwa perusahaan yang lebih tua cenderung memiliki penyelesaian audit yang lebih cepat.
\end{abstract}

Kata Kunci : Audit Report Lag, Ukuran KAP, Ukuran Perusahaan, Umur Perusahaan 


\section{PENGARUH UKURAN KAP, UKURAN PERUSAHAAN DAN UMUR PERUSAHAAN TERHADAPAUDIT REPORT LAG PADA PERUSAHAAN MANUFAKTUR YANG TERDAFTAR DI BEI TAHUN 2016-2018}

\section{PENDAHULUAN}

Laporan keuangan merupakan alat komunikasi yang berisi informasi yang dibuat oleh pihak manajemen perusahaan dalam bentuk data keuangan yang isinya adalah mengenai transaksi-transaksi dalam suatu perusahaan yang terjadi selama periode tertentu. Laporan keuangan memiliki peran yang sangat penting dalam proses pengukuran dan penilaian kinerja perusahaan serta bermanfaat untuk pengambilan keputusan. Laporan keuangan harus disusun sedemikian rupa hingga dapat memenuhi kebutuhan oleh pihak-pihak yang berkepentingan.

Laporan keuangan yang baik dan yang bisa meningkatkan kualitas laporan adalah laporan yang memenuhi karakteristik kualitatif yang telah ditetapkan oleh IAI. Karakteristik kualitatif tersebut terbagi atas karakteristik kualitatif fundamental dan karkteristik kualitaif peningkat. Karakteristik kualitatif fundamental terdiri atas relevansi, materialitas, representasi tepat, dan penerapan karakteristik kualitatif fundamental. Sementara itu, karakteristik kualiatif peningkat terbagi atas keterbandingan, keterverifikasian, ketepatwaktuan, keterpahaman, dan keterpahaman. (IAI, 2018:9)

Ketepatan waktu dalam penyampaian laporan keuangan sangat penting bagi pihak-pihak yang berkepentingan atas laporan keuangan. Ketepatan waktu berarti tersedianya informasi bagi pembuat keputusan pada waktu yang tepat sehingga dapat mempengaruhi keputusan mereka. Secara umum, semakin lawas suatu informasi maka semakin kurang berguna informasi tersebut (IAI, 2018:14). Ketepatan waktu atas laporan keuangan menjadi sangat penting bagi tiap perusahaan, terutama perusahaan yang terdaftar di Bursa Efek Indonesia. Ketepatan waktu dalam penyajian laporan keuangan dapat dilihat dari tanggal tutup buku laporan keuangan perusahaan sampai tanggal laporan audit. Faktor yang berpengaruh terhadap audit report lag salah satunya adalah ukuran kantor akuntan publik. Kantor Akuntan Publik (KAP) adalah suatu bentuk organisasi akuntan publik yang memperoleh izin sesuai dengan peraturan perundang-undangan, yang berusaha di bidang pemberian jasa profesional dalam praktek akuntan publik.

KAP di Indonesia dibagi menjadi KAP big four dan KAP non big four. KAP internasional atau yang biasa dikenal dengan KAP the big four diasumsikan dapat melaksanakan pekerjaan auditnya secara efisien dan memiliki tekanan waktu yang lebih tinggi untuk menyelesaikan audit tepat pada waktunya. Penyelesaian waktu audit secara tepat waktu tersebut selain dapat meningkatkan reputasi KAP juga dapat menjaga kepercayaan klien untuk memakai jasanya kembali untuk waktu yang akan datang. Penggunaan KAP big four juga dianggap sebagai bukti bahwa perusahaan bersungguh sungguh untuk patuh dalam peraturan dan melaporkan laporan keuangan perusahaannya dengan tepat waktu (Widiastuti dan Kartika, 2018). Hasil penelitian oleh Sumartini dan Widhiyani (2014) menunjukkan bahwa ukuran kantor akuntan publik berpengaruh negatif terhadap audit report lag. Sedangkan Widiastuti dan Kartika (2018) menunjukkan bahwa ukuran kantor akuntan publik berpengaruh positif terhadap audit report lag.

Selain ukuran KAP, faktor yang berpengaruh terhadap audit report lag selanjutnya adalah ukuran perusahaan. Ukuran perusahaan juga akan menjadi pertimbangan bagi para investor karena banyak perusahaan yang telah memiliki ukuran perusahaan yang sangat besar yang dalam arti telah berkembang dan memiliki banyak cabang di berbagai daerah, sehingga dalam menyajikan laporan keuangannya sudah memiliki pengalaman dan paham dalam menyajikan laporan keuangan tersebut.

Ukuran perusahaan dapat didefinisikan sebagai suatu skala di mana besar kecil perusahaan dapat dihitung dengan berbagai cara antara lain dinyatakan dalam total aset, nilai pasar saham, dan lain-lain. Sastrawan dan Latrini (2016) menunjukkan bahwa ukuran perusahaan berpengaruh negatif terhadap audit report lag. Ini mengindikasikan bahwa besar atau kecilnya jumlah aset yang dimiliki oleh perusahaan tidak mempengaruhi panjang atau pendeknya proses penyusunan laporan keuangan pada perusahaan tersebut. Sementara itu, menurut Arifuddin, dkk (2017) menyatakan bahwa ukuran perusahaan berpengaruh positif terhadap audit report lag. Ini mengindikasikan bahwa semakin besar ukuran perusahaan, maka semakin tinggi pula audit report lagnya.

Selain ukuran KAP dan ukuran perusahaan, faktor lain yang dapat menjadi pengaruh terhadap audit report lag adalah umur perusahaan. Fodio, dkk. (2015) menyatakan bahwa semakin lama umur perusahaan, semakin baik kemungkinan mereka memiliki prosedur pengendalian internal yang kuat. Berdasarkan penelitan yang dilakukan oleh Ariani, dkk (2018) menyatakan bahwa umur perusahaan Vol : 9, No : 1, 2021 
tidak berpengaruh terhadap audit report lag. Hal ini sejalan dengan penelitian yang dilakukan oleh ustman (2020) bahwasannya umur perusahaan tidak berpengaruh terhadap audit report lag. Sementara itu, penelitian yang dilakukan oleh Widhiasari dan Budhiarta (2016) menyatakan bahwa umur perusahaan berpengaruh positif dan signfikan terhadap audit report lag. Hasil senada juga ditunjukkan oleh Lianto dan Kusuma (2010) bahwasannya umur perusahaan berpengaruh terhadap audit report lag.

\section{KERANGKA TEORITIS DAN PENGEMBANGAN HIPOTESIS \\ 2.1 KERANGKA TEORITIS \\ 2.1.1 TEORI SINYAL}

Teori sinyal menyatakan bahwa terdapat kandungan informasi pada pengumuman suatu informasi yang dapat menjadi sinyal bagi investor dan pihak potensial lainnya dalam mengambil keputusan ekonomi. Suatu pengumuman dikatakan mengandung informasi apabila dapat memicu reaksi pasar, yaitu dapat berupa perubahan harga saham atau abnormal return. Apabila pengumuman tersebut memberikan dampak positif berupa kenaikan harga saham, maka pengumuman tersebut merupakan sinyal positif. Namun jika pengumuman tersebut memberikan dampak negatif, maka pengumuman tersebut merupakan sinyal negatif.

\subsubsection{AUDIT REPORT LAG}

Audit report lag adalah jumlah tanggal antara laporan keuangan tahunan dan laporan keuangan auditan. Audit report lag berkaitan dengan rentang waktu penyelesaian pelaksanaan audit laporan keuangan tahunan yang dihitung sejak tanggal tutup buku perusahaan, 31 desember, sampai tanggal yang tertera pada penyampaian laporan keuangan auditan (Naimi, 2010). Audit report lag merupakan jangka waktu penyelesaian audit yang diukur dengan berapa lama jumlah hari yang berlalu antara tanggal neraca dengan tanggal laporan audit ketika auditor menyelesaikan laporan auditnya. Jangka waktu audit sangat dikenal sebagai salah satu faktor yang memengaruhi kualias atas laporan keuangan perusahaan. Jangka waktu audit merupakan petunjuk yang dapat menjelaskan bahwa suatu laporan keuangan mampu memberikan informasi tepat waktu kepada para pemangku kepentingan (Fodio, dkk, 2015).

\subsubsection{TEORI AUDITING}

\section{a. Pengertian Audit}

Auditing merupakan serangkaian proses pemeriksaan mengenai laporan keuangan yang dilakukan oleh auditor dengan melihat kepada bukti-bukti maupun catatan pembukuan perusahaan yang tujuannya adalah untuk memberikan pendapat dan menilai apakah laporan keuangan yang disajikan bersifat wajar atau tidak.'

\section{b. Tujuan Audit}

Tujuan umum audit atas laporan keuangan adalah untuk menyatakan pendapat atas kewajaran laporan keuangan, dalam semua hal yang material, sesuai dengan prinsip-prinsip akuntansi yang berlaku umum.

\section{c. Jenis-Jenis Audit}

Ditinjau dari jenis pemeriksaan, audit dibedakan atas:

1. Management Audit (Operational Audit)

2. Pemeriksaan Ketaatan (Compliance Test)

3. Pemeriksaan Intern (Internal Audit)

\section{d. Standar Auditing}

Standar auditing yang telah ditetapkan dan disahkan oleh Institut Akuntan Publik Indonesia (2011:150.1-15.2) terdiri atas sepuluh standar yang dikelompokkan menjadi tiga kelompok besar, yaitu:

1. Standar Umum

Vol : 9, No: 1, 2021 
2. Standar pekerjaan lapangan

3. Standar Pelaporan

\subsubsection{UKURAN KANTOR AKUNTAN PUBLIK}

Kantor Akuntan Publik (KAP) adalah suatu bentuk instansi akuntan publik yang memperoleh izin dari Menteri Keuangan sesuai dengan peraturan perundang-undangan, yang berusaha di bidang pemberian jasa profesional dalam praktek akuntan publik (Widiastuti dan Kartika, 2018). Ukuran KAP dapat diukur berdasarkan jumlah klien dan presentase dari audit fees dalam usaha mempertahankan kliennya untuk tidak berpindah pada perusahaan audit yang lain. Pengukuran Kantor Akuntan Publik dibagi menjadi dua yaitu KAP the big four dan KAP non the big four. Berdasarkan ukurannya Kantor Akuntan Publik (KAP) dapat digolongkan kedalam 4 (empat) kategori, yaitu:

1. Kantor Akuntan Publik Internasional

2. Kantor Akuntan Publik Nasional

3. Kantor Akuntan Publik Regional

4. Kantor Akuntan Publik Lokal

\subsubsection{UKURAN PERUSAHAAN}

Ukuran perusahaan merupakan besar kecilnya suatu perusahaan yang di ukur dari besarnya total asset atau kekayaan yang dimiliki oleh suatu perusahaan. Indikator dilihat dari beberapa sudut pandang seperti total nilai aset, total penjualan, jumlah tenaga kerja, anak perusahaan, dan sebagainya. Besar kecilnya ukuran perusahaan juga dipengaruhi oleh kompleksitas operasional variabel dan intensitas transaksi penjualan. Pada umumnya perusahaan besar dimonitor oleh investor, pengawas permodalan, dan pemerintah. Dalam Peraturan Otoritas Jasa Keuangan Nomor 54 /POJK.04/2017 Tentang Bentuk Dan Isi Prospektus Dalam Rangka Penawaran Umum Dan Penambahan Modal Dengan Memberikan Hak Memesan Efek Terlebih Dahulu Oleh Emiten Dengan Aset Skala Kecil Atau Emiten Dengan Aset Skala Menengah, menyatakan bahwa perusahaan yang masuk dalam skala kecil adalah perusahaan yang memiliki total aset tidak lebih dari Rp50.000.000.000,00 (lima puluh miliar rupiah). Perusahaan dengan skala menengah, adalah perusahaan yang memiliki total aset lebih dari Rp50.000.000.000,00 (lima puluh miliar rupiah) sampai dengan Rp250.000.000.000,00 (dua ratus lima puluh miliar rupiah). Dan perusahaan yang tergolong dalam skala besar adalah perusahaan yang memiliki total aset lebih dari Rp250.000.000.000,00 (dua ratus lima puluh miliar rupiah).

\subsubsection{UMUR PERUSAHAAN}

Perusahaan didirikan untuk waktu yang tidak terbatas atau panjang, tidak didirikan untuk beberapa tahun saja. Umur perusahaan adalah lamanya perusahaan tersebut beroperasi (Widhiasari \& Budhiarta, 2016). Umur perusahaan dihitung dari tanggal berdirinya perusahaan tersebut hingga saat ini. Umumnya, perusahaan yang sudah lama berdiri telah memiliki banyak cabang atau usaha baru, tidak hanya di beberapa daerah namun juga sampai ke luar negeri. Banyaknya pemeriksaan yang harus dikaji oleh auditor serta berbagai transaksi dengan tingkat kompleksitas yang tinggi sehingga dapat memperpanjang proses audit ditunjukkan dengan besarnya skala operasi tersebut. Umur perusahaan digunakan untuk mengukur pengaruh lamanya perusahaan beroperasi terhadap ARL. Umur perusahaan dapat diukur dengan jumlah tahun sejak perusahaan berdiri, atau menggunakan jumlah tahun sejak perusahaan listing ke pasar modal. 


\subsection{PENGEMBANGAN HIPOTESIS}

\section{a. Pengaruh Ukuran KAP terhadap Audit Report Lag}

Ukuran Kantor Akuntan Publik merupakan besar kecilnya suatu KAP yang tergolong dari dua jenis, yaitu KAP yang berafiliasi dengan KAP Big Four dan KAP non Big Four. Ukuran KAP dapat dikatakan besar apabila KAP tersebut yang berafiliasi dengan Big Four mempunyai cabang dan jumlah kliennya besar serta memiliki tenaga professional diatas 25 orang. Sedangkan KAP kecil adalah KAP yang tidak berafiliasi dengan Big Four, tidak memiliki kantor cabang, jumlah kliennya kecil dan memiliki tenaga professional dibawah 25 orang.

KAP besar cenderung memiliki karyawan dalam jumlah yang besar, dapat mengaudit lebih efisien dan efektif, memiliki jadwal yang fleksibel sehingga memungkinkannya untuk menyelesaikan audit tepat waktu, dan memiliki dorongan yang lebih kuat untuk menyelesaikan auditnya lebih cepat guna menjaga reputasinya (Utami, 2006). Hal ini diperkuat oleh pendapat Prabandari dan Rustiana (2007) yang menyatakan bahwa KAP Big Four pada umumnya memiliki sumber daya yang lebih besar (kompetensi, keahlian, dan kemampuan auditor, fasilitas, sistem dan prosedur pengauditan yang digunakan, dll) dibandingkan dengan KAP non Big Four, sehingga KAP Big Four akan dapat menyelesaikan pekerjaan audit dengan lebih efektif dan efisien.

\section{b. Pengaruh Ukuran Perusahaan Terhadap Audit Report Lag}

Ukuran perusahaan merupakan gambaran besar kecilnya perusahaan yang ditentukan berdasarkan ukuran nominal misalnya jumlah kekayaan dan total penjualan perusahaan dalam satu periode penjualan (Rahayu 2011). Ukuran perusahaan dapat dilihat dari total asset yang dimiliki perusahaan. Hal yang mendasari hubungan antaraukuran perusahaan dengan audit report lag adalah perusahaan besar akan menyelesaikan proses auditnya lebih cepat dibandingkan perusahaan kecil, hal ini disebabkan oleh beberapa faktor yaitu manajemen perusahaan yang berskala besar cenderung diberikan insentif untuk mengurangi audit report lag karena perusahaan tersebut dimonitor secara ketat oleh investor, pengawas permodalan, dan pemerintah.

\subsection{KERANGKA BERPIKIR}

Gambar 1.1 Kerangka Berpikir

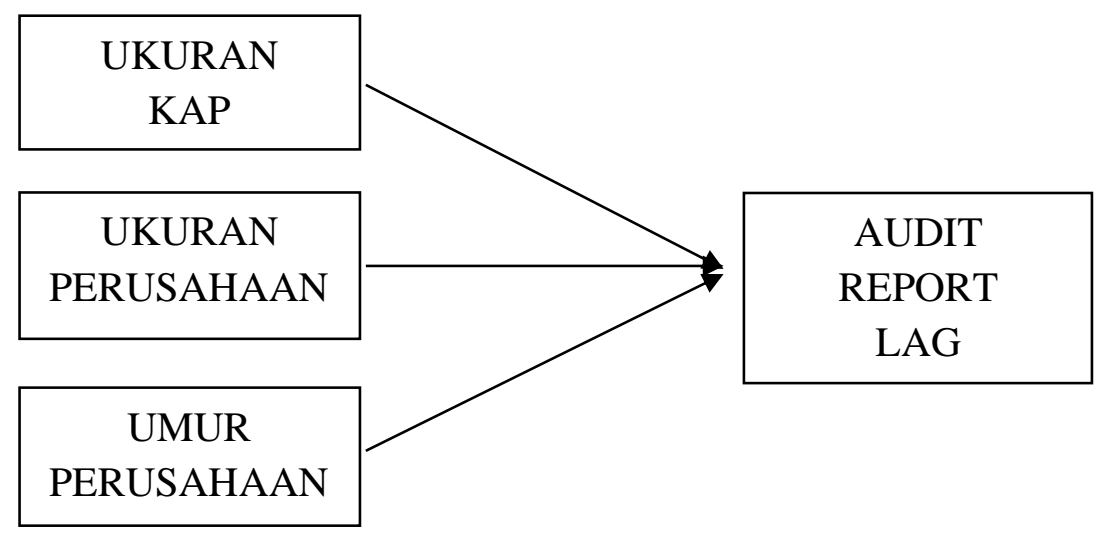

\subsection{HIPOTESIS}

H1 : Ukuran KAP berpengaruh terhadap audit report lag pada perusahaan manufaktur yang terdaftar di bursa efek indonesia tahun 2016-2018

H2 : Ukuran perusahaan berpengaruh terhadap audit report lag pada perusahaan manufaktur yang terdaftar di bursa efek indonesia tahun 2016-2018

H3 : Umur perusahaan berpengaruh terhadap audit report lag pada perusahaan manufaktur yang terdaftar di bursa efek indonesia tahun 2016-2018. 


\section{METODE PENELITIAN}

Penelitian ini dilakukan ada perusahaan manufaktur yang terdaftar di Bursa Efek Indonesia tahun 2016-2018 dan penelitian ini dilakukan pada bulan Maret 2020 sampai dengan selesai. Yang menjadi populasi dalam penelitian ini yaitu perusahaan manufaktur yang terdaftar di Bursa Efek Indonesia tahun 2016-2018. Pemilihan sampel penelitian dilakukan dengan cara purposive sampling. Hal tersebut dilakukan untuk menghindari kesalahan dalam proses selanjutnya yang bisa memengaruhi hasil analisa. Sampel yang digunakan adalah sampel yang memiliki kriteria sebagai berikut

1. Perusahaan manufaktur yang terdaftar di Bursa Efek Indonesia periode 2016-2018.

2. Perusahaan yang delisting selama periode penelitian.

3. Perusahaan yang memiliki total aset lebih dari 500 milyar.

4. Perusahaan yang hanya menggunakan mata uang rupiah ( $\mathrm{Rp})$ dalam mempublikasikan laporan keuangan.

\subsection{Variabel Penelitian dan Defenisi Operasional}

a. Variabel Penelitian

Variabel yang digunakan dalam penelitian diantaranya terdiri dari variabel depenen (terikat) dan variabel independen (tidak terikat).

1. Variabel dependen

Variabel dependen dalam penelitian ini adalah audit report lag.

2. Variabel independen

Variabel independen dalam penelitian ini adalah:

$\mathrm{X} 1$ = Ukuran Kantor Akuntan Publik

$\mathrm{X} 2=$ Ukuran Perusahaan

X3 = Umur Perusahaan

\section{b. Defenisi Operasional}

\section{Variabel Dependen : Audit Report Lag (ARL)}

Audit report lag (ARL) adalah rentang waktu penyelesaian audit yang digunakan oleh auditor mulai dari tanggal tutup buku perusahaan hingga tanggal laporan audit. Pengukuran audit report lag dalam penelitian ini yaitu menggunakan tanggal tutup buku perusahaan (31 Desember) sampai tanggal diterbitkannya laporan auditan. Perhitungan audit report lag dengan rumus berikut:

\section{Audit Report Lag $=$ Tanggal Publikasi Laporan Audit - Tanggal Penutupan Buku Laporan Keuangan 31 Desember}

\section{Variabel Independen}

\section{a. Ukuran Kantor Akuntan Publik}

Kantor akuntan publik merupakan sebuah instansi yang mewadahi para akuntan publik untuk menjalankan pekerjaannya dalam bidang akuntansi. Ukuran kantor akuntan publik dilihat dari besar atau kecilnya kantor akuntan publik yang mengaudit perusahaan. Pengukuran menggunakan variabel dummy, KAP big 4 diberi angka 1 sedangkan KAP non-big 4 diberi angka 0.

\section{b. Ukuran Perusahaan}

Ukuran perusahaan dilihat dari besar kecilnya suatu perusahaan dengan mengukur menggunakan nilai total aset, total penjualan, total nilai buku perusahaan, jumlah tenaga kerja dan area ekspansi perusahaan. Dalam penelitian ini, Ukuran Perusahaan diukur dengan menggunakan total aset perusahaan dengan menggunakan log size (natural logaritma) untuk menghaluskan besarnya angka dan menyamarkan ukuran regresi.

$$
\text { Ukuran perusahaan }=\operatorname{Ln}(\text { total aset })
$$




\section{c. Umur Perusahaan}

Umur perusahaan digunakan untuk mengukur pengaruh lamanya perusahaan beroperasi terhadap ARL. Umur perusahaan dapat diukur dengan jumlah tahun sejak perusahaan berdiri, atau menggunakan jumlah tahun sejak perusahaan listing ke pasar modal. Dalam penelitian ini, Umur Perusahaan dihitung dari tanggal berdirinya perusahaan sampai tanggal tutup buku perusahaan.

\section{Umur Perusahaan $=$ Tahun tutup buku perusahaan-Tahun berdirinya perusahaan}

\subsection{Teknik Pengumpulan Data}

Data yang digunakan berasal dari laporan keuangan perusahaan yang terdaftar di Bursa Efek Indonesia periode 2016-2018. Data tersebut diperoleh dari Indonesia Stock Exchange (IDX) dengan periode 2016-2018. Sumber data diperoleh dengan mengakses situs resmi Bursa Efek Indonesia yaitu www.idx.com.

\subsection{Teknik Analisis Data}

Analisa data yang digunakan adalah analisis kuantitatif yang dinyatakan dengan angka-angka dan penghitungannya dengan menggunakan metode statistik yang dibantu dengan program SPSS 20.

\section{a. Analisis Statistik Deskriptif}

Analisis deskritif digunakan untuk mengambarkan variabel-variabel dalam penelitian, yaitu variabel dependen dan variabel independen. Alat yang digunakan adalah nilai maksimum, nilai ratarata (mean) dan deviasi standar. Nilai minimum digunakan untuk mengetahui jumlah terkecil data yang digunakan. Nilai maksimum digunakan untuk mengetahui jumlah terbesar data yang digunakan. Mean digunakan untuk mengetahui rata-rata data yang digunakan. Standar deviai digunakan untuk mengetahui seberapa besar data yang besangkuan bervariasi dari rata-rata serta untuk mengidentifikasi dengan standar ukuran setiap variabel.

\section{b. Uji Asumsi Klasik}

Uji asumsi klasik yang dgunakan pada umumnya yaitu uji normalitas, uji multikolinearitas, uji heteroskedastisitas, dan uji autokorelasi.

\section{Uji Multikoliniearitas}

Untuk mendeteksi adanya multikolinearitas dapat dilihat dari Variance Inflation Factor (VIF) dan nilai tolerance melalui program SPSS. Nilai cut off yang umum dipakai untuk menunjukkan adanya multikolinearitas adalah nilai tolerance $<0,10$ atau sama dengan nilai VIF $>10$. Jika nilai VIF $>10$ maka terjadi multikolinearitas. Dan sebaliknya apabila VIF $<10$ maka tidak terjadi multikolinearitas (Ghozali, 2006:91).

\section{Uji Heteroskedastisitas}

Cara untuk mengetahui apakah terjadi heteroskedastisitas atau tidak yaitu melihat grafik Ploi antara nilai prdiksi variabel dependen yaitu ZPRED dengan residualnya SRESID. Tidak terjadi heteroskedastisitas yaitu apabila tidak ada pola yang jelas, serta titik-titik menyebar diatas dan dibawah angka 0 pada sumbu Y.

\section{Uji Autokorelasi}

Cara untuk mengetahui apakah autokorelasi atau tidak yaitu dengan menggunakan run test. Run test sebagai bagian dari statistik non-parametrik dapat pula digunakan untuk menguji apakah antar residual terdapat korelasi yang tinggi. Jika antar residual tidak terdapat hubungan korelasi maka dikatakan bahwa residual adalah acak atau random. Run test digunakan untuk melihat apakah data rsidual terjadi secara random atau tidak (sistematis). Tidak terjadi autokorelasi yaitu apabila probabilitas signifikan lebih besar dari $\alpha=0,05$. 


\section{c. Analisis Regresi Berganda}

Analisis data untuk pengujian hipotesis dengan menggunakan analisis regresi berganda. Analisis regresi dalam penelitian ini digunakan untuk mengetahui pengaruh ukuran kap, ukuran perusahaan dan umur perusahaan terhadap audit report lag. Adapun bentuk model yang akan diuji dalam peneltian ini, yaitu:

$$
A R L=\alpha+\beta_{1} \text { KAP }+\beta_{2} \text { SIZE }+\beta_{3} \text { AGE }+\varepsilon_{i, t}
$$

Keterangan:
$\mathrm{ARL} \quad=$ Audit Report Lag
$\mathrm{KAP}=$ Ukuran KAP
SIZE $=$ Ukuran Perusahaan
$\mathrm{AGE}=$ Umur Perusahaan
$\varepsilon_{\mathrm{i}, \mathrm{t}} \quad=$ Koefisien Error

\section{d. Pengujian Hipotesis}

\section{Uji Statistik T}

Uji statistik t pada dasarnya menunjukkan seberapa jauh pengaruh satu variabel independen secara individual dalam menenrangkan variasi-variasi variabel dependen. Kriteria yang digunakan dalam menerima atau menolak hipotesis sebagai berikut:

Hipotesis diterima jika $t_{\text {hitung }}>t_{\text {tabel }}$ dengan tingkat signifikansi $<5 \%$

Hipotesis ditolak jika $\mathrm{t}_{\text {hitung }}<\mathrm{t}_{\text {tabel }}$ dengan tingkat signifikansi $>5 \%$ diterima.

\section{Koefisien Determinasi $\left(\mathbf{R}^{2}\right)$}

Penelitian ini menggunakan analisis koefisien determinasi, dengan tujuan untuk menghibur seberap jauh kemampuan model dalam menerangkan variabel dependen. Nilai $\mathrm{R}^{2}$ yang kecil berarti kemamppuan variabel-variabel independen dalam menjelaskan variabel dependen amat terbatas. Nilai yang mendekati satu berarti variabel-variabel independen memberikan hampir semua informasi yang dibutuhkan untuk memprediksi variabel independen.

\section{HASIL ANALISIS DAN PEMBAHASAN}

\section{Tabel 4.1 Penentuan Sampel}

\begin{tabular}{|c|l|c|}
\hline No & \multicolumn{1}{|c|}{ Kriteria } & Jumlah \\
\hline 1. & $\begin{array}{l}\text { Perusahaan manufaktur yang terdaftar di Bursa Efek Indonesia selama periode 2016- } \\
\text { 2018. }\end{array}$ & 165 \\
\hline 2. & Perusahaan yang delisting selama periode penelitian. & 3 \\
\hline 3. & $\begin{array}{l}\text { Perusahaan yang tidak menyajikan laporan keuangan tahunan (annual report) selama } \\
\text { periode penelitian. }\end{array}$ & 37 \\
\hline 4. & $\begin{array}{l}\text { Perusahaan yang menggunakan mata uang asing dalam mempublikasikan laporan } \\
\text { keuangan. }\end{array}$ & 26 \\
\hline 5. & $\begin{array}{l}\text { Perusahaan yang tidak menyediakan data-data yang dibutuhkan oleh peneliti terkait } \\
\text { variabel-variabel penelitian. }\end{array}$ & 24 \\
\hline 6. & Data Outlier. & 12 \\
\hline Jumlah Sampel Perusahaan & 63 \\
\hline \multicolumn{2}{|l|}{ Total keseluruhan selama 3 tahun } & 189 \\
\hline
\end{tabular}

Sumber: Bursa Efek Indonesia, Data yang diolah peneliti (2020) 
Tabel 4.2 Sampel Penelitian

\begin{tabular}{|c|c|c|}
\hline 1 & Akasha Wira International Tbk & ADES \\
\hline 2 & Aneka Gas Industri Tbk & AGII \\
\hline 3 & Argha Karya Prima Industry Tbk & AKPI \\
\hline 4 & Alakasa Industrindo Tbk & ALKA \\
\hline 5 & Alumindo Light Metal Industry Tbk & ALMI \\
\hline 6 & Asiaplast Industries Tbk & APLI \\
\hline 7 & Asahimas Flat Glass Tbk & AMFG \\
\hline 8 & Astra International Tbk & ASII \\
\hline 9 & Astra Otoparts Tbk & AUTO \\
\hline 10 & Saranacentral Bajatama Tbk & BAJA \\
\hline 11 & Sepatu Bata Tbk & BATA \\
\hline 12 & Primarindo Asia Infrastructure Tbk & BIMA \\
\hline 13 & Betonjaya Manunggal Tbk & BTON \\
\hline 14 & Budi Starch and Sweetener Tbk & BUDI \\
\hline 15 & PT Wilmar Cahaya Indonesia Tbk & CEKA \\
\hline 16 & Chitose International Tbk & CINT \\
\hline 17 & Charoen Pokphand Indonesia Tbk & CPIN \\
\hline 18 & Darya Varia Laboratoria Tbk & DVLA \\
\hline 19 & Ekadharma International Tbk & EKAD \\
\hline 20 & Gunawan Dianjaya Steel Tbk & GDST \\
\hline 21 & Gudang Garam Tbk & GGRM \\
\hline 22 & Hanjaya Mandala Sampoerna Tbk & HMSP \\
\hline 23 & Indofood CBP Sukses Makmur Tbk & ICBP \\
\hline 24 & Inti Agri Resources Tbk & IIKP \\
\hline 25 & Indomobil Sukses Internasional Tbk & IMAS \\
\hline 26 & Indofarma Tbk & INAF \\
\hline 27 & Indal Aluminium Industry Tbk & INAI \\
\hline 28 & Intan Wijaya International Tbk & INCI \\
\hline 29 & Indofood Sukses Makmur Tbk & INDF \\
\hline 30 & Indocement Tunggal Prakasa Tbk & INTP \\
\hline 31 & Kimia Farma Tbk & KAEF \\
\hline 32 & Keramika Indonesia Assosiasi Tbk & KIAS \\
\hline 33 & Kedaung Indah Can Tbk & $\mathrm{KICI}$ \\
\hline 34 & Kino Indonesia Tbk & KINO \\
\hline 35 & Kedawung Setia Industrial Tbk & KDSI \\
\hline 36 & Lionmesh Prima Tbk & LMSH \\
\hline
\end{tabular}




\begin{tabular}{|l|l|l|}
\hline 37 & Malindo Feedmill Tbk & MAIN \\
\hline 38 & Martina Berto Tbk & MBTO \\
\hline 39 & Multi Bintang Indonesia Tbk & MLBI \\
\hline 40 & Mulia Industrindo Tbk & MLIA \\
\hline 41 & Mustika Ratu Tbk & MRAT \\
\hline 42 & Pelangi Indah Canindo Tbk & PICO \\
\hline 43 & Prima Alloy Steel Universal Tbk & PRAS \\
\hline 44 & Ricky Putra Globalindo Tbk & RICY \\
\hline 45 & Bentoel Internasional Investama Tbk & RMBA \\
\hline 46 & Nippon Indosari Corpindo Tbk & ROTI \\
\hline 47 & Supreme Cable Manufacturing Corporation Tbk & SCCO \\
\hline 48 & Industri Jamu dan Farmasi Sido Tbk & SIDO \\
\hline 49 & Sierad Produce Tbk & SIPD \\
\hline 50 & Semen Indonesia (Persero) Tbk & SMGR \\
\hline 51 & Selamat Sempurna Tbk & SMSM \\
\hline 52 & Suparma Tbk & SPMA \\
\hline 53 & Indo Acitama Tbk & SRSN \\
\hline 54 & Star Petrochem Tbk & STAR \\
\hline 55 & Mandom Indonesia Tbk & TCID \\
\hline 56 & Tirta Mahakam Resources Tbk & TIRT \\
\hline 57 & Surya Toto Indonesia Tbk & TOTO \\
\hline 58 & Trisula International Tbk & TRIS \\
\hline 59 & Trias Sentosa Tbk & TRST \\
\hline 60 & Tempo Scan Pacific Tbk & TSPC \\
\hline 61 & Ultra Jaya Milk Industry and Trading Company Tbk & ULTJ \\
\hline 62 & Wismilak Inti Makmur Tbk & WIIM \\
\hline 63 & Yanaprima Hastapersada Tbk & YPAS \\
\hline & & \\
\hline
\end{tabular}

Tabel 4.3 Hasil Statistik Deskriptif

\begin{tabular}{|l|r|r|r|r|r|}
\hline \multicolumn{7}{|c|}{ Descriptive Statistics } \\
\hline X1 & \multicolumn{1}{|c|}{ N } & \multicolumn{1}{|c|}{ Minimum } & Maximum & \multicolumn{1}{c|}{ Mean } & Std. Deviation \\
X2 & 188 &,- 39 & 1,00 &, 2531 &, 40215 \\
X3 & 188 & 14,46 & 21,63 & 17,3712 & 1,28631 \\
Y & 188 & $-14,45$ & 75,25 & 24,1011 & 11,91922 \\
Valid N (listwise) & 188 & 12,07 & 77,19 & 47,5563 & 9,78473 \\
\hline
\end{tabular}

Sumber: Hasil Pengujian Data SPSS 2020 
Tabel 4.4 Hasil Uji Normalitas

One-Sample Kolmogorov-Smirnov Test

\begin{tabular}{|c|c|c|}
\hline & & $\begin{array}{c}\text { Unstandardized } \\
\text { Residual }\end{array}$ \\
\hline $\begin{array}{l}\text { N } \\
\text { Normal Parameters }{ }^{a, b} \\
\text { Most Extreme Differences } \\
\text { Kolmogorov-Smirnov Z } \\
\text { Asymp. Sig. (2-tailed) }\end{array}$ & $\begin{array}{l}\text { Mean } \\
\text { Std. Deviation } \\
\text { Absolute } \\
\text { Positive } \\
\text { Negative }\end{array}$ & $\begin{array}{r}188 \\
0 \mathrm{E}-7 \\
9,49658149 \\
, 091 \\
, 057 \\
-, 091 \\
1,252 \\
, 087\end{array}$ \\
\hline
\end{tabular}

Sumber: Hasil Pengujian Data SPSS 2020

Gambar 4.1. Hasil Uji Normalitas Grafik Histogram

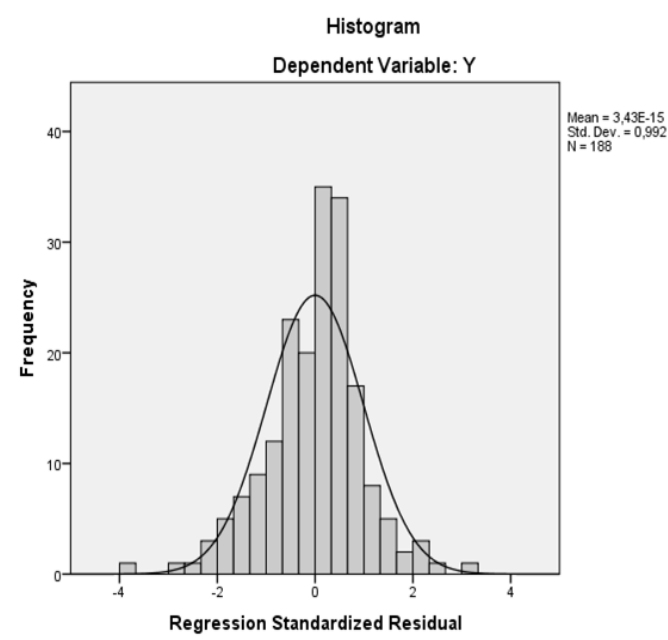

Sumber: Hasil Pengujian Data SPSS 2020

Gambar 4.2 Hasil Uji Normalitas Grafik Normal Plot

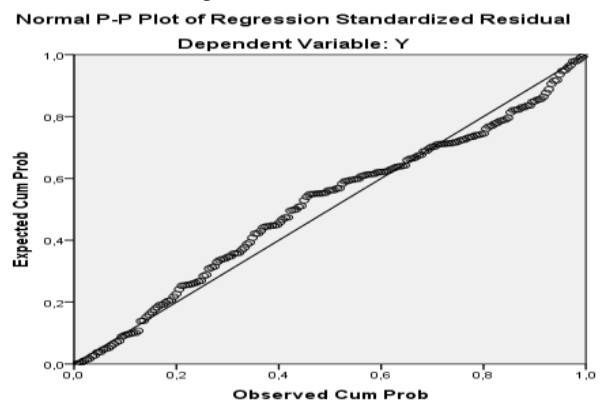

Sumber: Hasil Pengujian Data SPSS 2020

Tabel 4.5 Hasil Pengujian Multikolinieralitas

Coefficients $^{a}$

\begin{tabular}{|c|c|c|c|c|c|c|c|}
\hline \multirow[t]{2}{*}{ Model } & \multicolumn{2}{|c|}{$\begin{array}{l}\text { Unstandardized } \\
\text { Coefficients }\end{array}$} & $\begin{array}{c}\text { Standardized } \\
\text { Coefficients }\end{array}$ & \multirow[t]{2}{*}{$t$} & \multirow[t]{2}{*}{ Sig. } & \multicolumn{2}{|c|}{ Collinearity Statistics } \\
\hline & $\mathrm{B}$ & Std. Error & Beta & & & Tolerance & VIF \\
\hline (Constant) & 63,848 & 11,217 & & 5,692 & ,000 & & \\
\hline $\mathrm{X} 1$ & 1,006 & 2,183 & 041 & ,461 & ,646 & ,636 & 1,573 \\
\hline $\mathrm{X} 2$ &,- 703 & ,663 &,- 092 & $-1,061$ & ,290 & ,674 & 1,484 \\
\hline X3 &,- 180 & ,063 &,- 219 & $-2,863$ &, 005 & ,875 & 1,143 \\
\hline
\end{tabular}

a. Dependent Variable: $Y$

Sumber: Hasil Pengujian Data SPSS 2020 
Tabel 4.6 Hasil Pengujian Heteroskedastisitas

\begin{tabular}{|c|c|c|c|c|c|c|}
\hline \multicolumn{7}{|c|}{ Correlations } \\
\hline & & & $\mathrm{X} 1$ & $\mathrm{X} 2$ & X3 & $\mathrm{Y}$ \\
\hline \multirow{12}{*}{ Spearman's rho } & & Correlation Coefficient & 1,000 &, $556^{* *}$ &, $326^{* *}$ &,- 035 \\
\hline & $\mathrm{X} 1$ & Sig. (2-tailed) & &, 000 &, 000 & ,637 \\
\hline & & $\mathrm{N}$ & 188 & 188 & 188 & 188 \\
\hline & & Correlation Coefficient &, $556^{* *}$ & 1,000 &, $359^{* *}$ &,- 058 \\
\hline & $\mathrm{x} 2$ & Sig. (2-tailed) &, 000 & &, 000 & ,429 \\
\hline & & $\mathrm{N}$ & 188 & 188 & 188 & 188 \\
\hline & & Correlation Coefficient &, $326^{\star *}$ & ,359** & 1,000 &,- 120 \\
\hline & $\mathrm{X} 3$ & Sig. (2-tailed) &, 000 & ,000 & & , 100 \\
\hline & & $\mathrm{N}$ & 188 & 188 & 188 & 188 \\
\hline & & Correlation Coefficient &,- 035 &,- 058 &,- 120 & 1,000 \\
\hline & $\mathrm{Y}$ & Sig. (2-tailed) &, 637 & ,429 & , 100 & \\
\hline & & $\mathrm{N}$ & 188 & 188 & 188 & 188 \\
\hline
\end{tabular}

*. Correlation is significant at the 0.01 level (2-tailed)

Sumber: Hasil Pengujian Data SPSS 2020

Tabel 4.7 Hasil Pengujian Autokorelasi

\begin{tabular}{|l|r|}
\hline \multicolumn{2}{|c|}{ Runs Test } \\
\hline Test Value $^{\mathrm{a}}$ & $\begin{array}{c}\text { Unstandardized } \\
\text { Residual }\end{array}$ \\
Cases < Test Value & 1,48549 \\
Cases >= Test Value & 94 \\
Total Cases & 94 \\
Number of Runs & 188 \\
Z & 93 \\
Asymp. Sig. (2-tailed) &,- 293 \\
\hline
\end{tabular}

a. Median

Sumber: Hasil Pengujian Data SPSS 2020

Tabel 4.9 Hasil Uji Parsial

Coefficients $^{a}$

\begin{tabular}{|c|c|c|c|c|c|c|c|}
\hline \multirow[t]{2}{*}{ Model } & \multicolumn{2}{|c|}{$\begin{array}{l}\text { Unstandardized } \\
\text { Coefficients }\end{array}$} & $\begin{array}{c}\text { Standardized } \\
\text { Coefficients }\end{array}$ & \multirow[t]{2}{*}{$t$} & \multirow[t]{2}{*}{ Sig. } & \multicolumn{2}{|c|}{ Collinearity Statistics } \\
\hline & $\mathrm{B}$ & Std. Error & Beta & & & Tolerance & VIF \\
\hline (Constant) & 63,848 & 11,217 & & 5,692 &, 000 & & \\
\hline $\mathrm{X} 1$ & 1,006 & 2,183 &, 041 & ,461 & ,646 & ,636 & 1,573 \\
\hline $\mathrm{X} 2$ &,- 703 & ,663 &,- 092 & $-1,061$ & 290 & ,674 & 1,484 \\
\hline X3 &,- 180 &, 063 &,- 219 & $-2,863$ & ,005 & ,875 & 1,143 \\
\hline
\end{tabular}

a. Dependent Variable: $Y$

Sumber: Hasil Pengujian Data SPSS 2020

Tabel 4.10 Hasil Uji Simultan

\begin{tabular}{|c|c|c|c|c|c|c|}
\hline \multicolumn{7}{|c|}{ ANOVA $^{a}$} \\
\hline & & Sum of Squares & $d f$ & Mean Square & $\mathrm{F}$ & Sig. \\
\hline \multirow{3}{*}{1} & Regression & 1038,968 & 3 & \multirow{3}{*}{$\begin{array}{r}346,323 \\
91,655\end{array}$} & \multirow[t]{3}{*}{3,779} & \multirow[t]{3}{*}{, $012^{b}$} \\
\hline & Residual & 16864,606 & 184 & & & \\
\hline & Total & 17903,574 & 187 & & & \\
\hline
\end{tabular}

a. Dependent Variable: $Y$

b. Predictors: (Constant), X3, X2, X1

Sumber: Hasil Pengujian Data SPSS 2020 
Tabel 4.11 Ringkasan Hasil Uji Hipotesis

\begin{tabular}{|c|c|c|c|}
\hline No & Hipotesis & Alat Uji & Hasil \\
\hline 1. & $\begin{array}{l}\text { Ukuran Kantor Akuntan Publik } \\
\text { berpengaruh terhadap Audit Report } \\
\text { Lag pada perusahaan manufaktur } \\
\text { yang terdaftar di BEI. }\end{array}$ & $\begin{array}{l}\text { Uji Parsial } \\
\text { (Uji T) }\end{array}$ & $\begin{array}{l}\text { Nilai thitung sebesar } 0,461< \\
1,65318 \text { pada tabel sedangkan } \\
\text { tingkat signifikansi } 0,646 \text { yang } \\
\text { berarti lebih besar dari pada } 0,05, \\
\text { artinya } \mathrm{H}_{1} \text { ditolak. }\end{array}$ \\
\hline 2. & $\begin{array}{l}\text { Ukuran Perusahaan berpengaruh } \\
\text { terhadap Audit Report Lag pada } \\
\text { perusahaan manufaktur yang } \\
\text { terdaftar di BEI. }\end{array}$ & $\begin{array}{l}\text { Uji Parsial } \\
\text { (Uji T) }\end{array}$ & 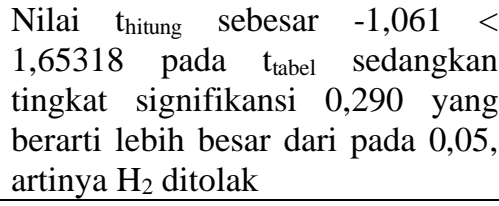 \\
\hline 3. & $\begin{array}{l}\text { Umur Perusahaan berpengaruh } \\
\text { terhadap Audit Report Lag pada } \\
\text { perusahaan manufaktur yang } \\
\text { terdaftar di BEI. }\end{array}$ & $\begin{array}{l}\text { Uji Parsial } \\
\text { (Uji T) }\end{array}$ & 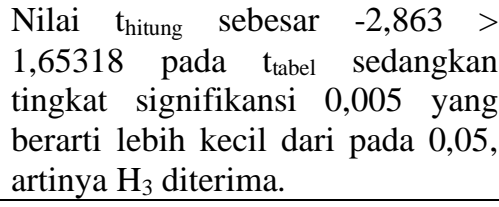 \\
\hline 4. & $\begin{array}{l}\text { Ukuran KAP, Ukuran Perusahaan dn } \\
\text { Umur Perusahaan berpengaruh } \\
\text { terhadap Audit Report Lag pada } \\
\text { perusahaan manufaktur yang } \\
\text { terdaftar di BEI. }\end{array}$ & $\begin{array}{c}\text { Uji } \\
\text { Simultan } \\
\text { (Uji F) }\end{array}$ & $\begin{array}{l}\text { Nilai } F_{\text {hitung }} \text { sebesar } 3,779 \text { dengan } \\
\text { nilai } F_{\text {tabel }} \text { sebesar 2,65, maka } \\
\mathrm{F}_{\text {hitung }}>\mathrm{F}_{\text {tabel. }} \text { Sedangkan tingkat } \\
\text { signifikansi } 0,012 \text { yang berarti } \\
\text { lebih kecil dari } 0,05 \text {, maka dapat } \\
\text { disimpulkan bahwa } \mathrm{H}_{4} \text { diterima. }\end{array}$ \\
\hline
\end{tabular}

Tabel 4.12 Hasil Uji Koefisien Determinasi

\begin{tabular}{|l|r|r|r|r|r|}
\hline Model & R & R Square & $\begin{array}{c}\text { Adjusted R } \\
\text { Square }\end{array}$ & $\begin{array}{c}\text { Std. Error of the } \\
\text { Estimate }\end{array}$ & Durbin-Watson \\
\hline 1 &, $241^{\mathrm{a}}$ &, 058 &, 043 & 9,57369 & 1,968 \\
\hline
\end{tabular}

a. Predictors: (Constant), X3, X2, X1

b. Dependent Variable: $Y$

Sumber: Hasil Pengujian Data SPSS 2020

\section{PEMBAHASAN}

\section{Pengaruh Ukuran KAP terhadap Audit Report Lag}

Berdasarkan uji hipotesis $\mathrm{t}$ menunjukkan nilai $\mathrm{t}_{\text {hitung }}$ sebesar $0,461<1,65318$ pada $\mathrm{t}_{\text {tabel }}$ sedangkan tingkat signifikansi 0,646 yang berarti lebih besar dari pada 0,05 , artinya $\mathrm{H}_{1}$ ditolak, atau ukuran KAP tidak berpengaruh terhadap Audit Report Lag. Hasil penelitian ini sejalan penelitian dengan Sumartini dan Widiyani (2014) yang menyatakan bahwa ukuran KAP tidak berpengaruh terhadap audit report lag. Hasil penelitian ini menunjukkan bahwa perusahaan dalam satu industri yang diaudit oleh KAP big four memiliki jangka waktu penyelesaian audit yang tidak jauh berbeda dengan yang diaudit KAP non big four. Banyak tidaknya klien dalam satu KAP itu menunjukkan pengalaman dan pemahaman tentang kondisi lingkungan perusahaan yang diaudit tidak hanya dimiliki oleh KAP big four, namun juga dimiliki oleh KAP non big four. Dan dalam proses mengaudit, masing-masing kantor akuntan publik tentu ingin menyelesaikan audit secara tepat waktu dalam jangka yang telah ditetapkan. Baik KAP yang bersangkutan adalah KAP big four ataupun non big four. Hasil penelitian ini bertentangan dengan penelitian yang dilakukan oleh Iskandar dan Trisnawati (2010), Widiastuti dan Kartika (2018) yang menyatakan bahwa ukuran KAP berpengaruh terhadap Audit Report Lag.

\section{Pengaruh Ukuran Perusahaan terhadap Audit Report Lag}

Berdasarkan uji hipotesis t menunjukkan nilai thitung sebesar $-1,061<1,65318$ pada t-tabel sedangkan tingkat signifikansi 0,290 yang berarti lebih besar dari pada 0,05, artinya $\mathrm{H} 2$ ditolak, atau ukuran perusahaan tidak berpengaruh terhadap Audit Report Lag. Hasil Penelitian ini sejalan 


\section{PENGARUH UKURAN KAP, UKURAN PERUSAHAAN DAN UMUR PERUSAHAAN TERHADAPAUDIT REPORT LAG PADA PERUSAHAAN MANUFAKTUR YANG TERDAFTAR DI BEI TAHUN 2016-2018}

penelitian dengan Lianto dan Kusuma (2010) yang menyatakan bahwa ukuran perusahaan tidak berpengaruh terhadap audit report lag. Semua perusahaan senantiasa diawasi oleh para investor, regulator, dan berbagai pihak lain sehingga setiap perusahaan dituntut untuk dapat segera menyelesaikan pelaksanaan audit laporan keuangan tahunan. Hasil penelitian yang sejalan juga ditunjukkan oleh Lestari dan Aggraini (2015) menyatakan bahwa ukuran perusahaan tidak berpengaruh terhadap audit report lag. Baik perusahaan yang memiliki aset yang besar maupun kecil, keduanya tidak dapat mempengaruhi panjang atau pendeknya proses penyusunan laporan keuangan pada perusahaan karena kedua jenis perusahaan tersebut mendapatkan tekanan untuk menyampaikan laporan keuangannya secara tepat waktu. Tekanan itu dapat berasal dari investor itu sendiri ataupun berasal dari BAPEPAM melalui peraturan penyampaian laporan keuangan. Hasil penelitian ini tidak sejalan dengan penelitian yang dilakukan oleh Ariani dan Budhiarta (2014), Puspitasari dan Latrini (2014), Widiastuti dan Kartika (2018) dan Ariani dan Bawono (2018) yang menyatakan bahwa ukuran perusahaan berpengaruh terhadap audit report lag.

\section{Pengaruh Umur Perusahaan terhadap Audit Report Lag}

Berdasarkan uji hipotesis $\mathrm{t}$ menunjukkan nilai $\mathrm{t}_{\text {hitung }}$ sebesar $-2,863>1,65318$ pada $\mathrm{t}_{\text {tabel }}$ sedangkan tingkat signifikansi 0,005 yang berarti lebih kecil dari pada 0,05 , artinya $\mathrm{H}_{3}$ diterima, atau umur perusahaan berpengaruh terhadap Audit Report Lag. Hasil Penelitian ini sejalan penelitian dengan Soemargani dan Mustikawati (2015) yang menyatakan bahwa umur perusahaan berpengaruh terhadap audit report lag. Semakin lama umur perusahaan, investor akan menilai bahwa perusahaan tersebut akan semakin efisien sehingga informasi yang relevan dapat disajikan tepat waktu. Oleh karena itu, semakin lama umur perusahaan maka Audit report lag yang ter jadi akan semakin singkat. Hal tersebut dikarenakan perusahaan yang memiliki umur lebih lama dinilai lebih mampu dan terampil dalam mengumpulkan, memproses, dan menghasilkan informasi pada saat diperlukan karena telah memiliki pengalaman yang cukup banyak. Penelitian ini bertentangan dengan penelitian yang dilakukan oleh Widiastuti dan Kartika (2018), dan Manda, dkk (2016) yang menyatakan bahwa umur perusahaan tidak berpengaruh terhadap audit report laG.

\section{Pengaruh Ukuran KAP, Ukuran Perusahaan dan Umur Perusahaan terhadap Audit Report Lag}

Berdasarkan hasil pengolahan SPSS menunjukkan nilai Fhitung sebesar 3,779 dengan

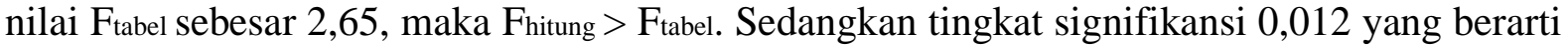
lebih kecil dari 0,05, maka dapat disimpulkan variabel ukuran KAP, ukuran perusahaan dan umur perusahaan berpengaruh secara simultan (bersama-sama) terhadap Audit Report Lag.

\section{KESIMPULAN DAN SARAN}

Berdasarkan hasil penelitian dan pembahasan yang telah dikemukakan pada bagian sebelumnya, maka dapat diambil kesimpulan sebagai berikut :

1. Ukuran KAP secara parsial tidak berpengaruh terhadap Audit Report Lag. Hal ini dibuktikan dengan hasil nilai thitung pada variabel Ukuran KAP sebesar 0,461 < nilai ttabel 1,65318 nilai $(0,461<1,65318)$ dan nilai signifikansi sebesar $0,646>0,05$, yang berarti $\mathrm{H} 1$ ditolak

2. Ukuran Perusahaan secara parsial tidak berpengaruh terhadap Audit Report Lag. Hal ini dibuktikan dengan hasil nilai $t_{\text {hitung }}$ pada variabel Ukuran Perusahaan $-1,061<$ nilai $t_{\text {tabel }} 1,65318$ $(-1,061<1,65318)$ dan nilai signifikansi sebesar, 0,290 > 0,05, yang berarti $\mathrm{H}_{2}$ ditolak.

3. Umur Perusahaan secara parsial berpengaruh terhadap Audit Report Lag. Hal ini dibuktikan dengan hasil nilai $t_{\text {hitung }}$ pada variabel Ukuran Perusahaan $-2,863<$ nilai $t_{\text {tabel }} 1,65318 \quad(-2,863>1$, 65318) dan nilai signifikansi sebesar, $0,005<0,05$, yang berarti $\mathrm{H}_{3}$ diterima.

4. Ukuran KAP, Ukuran Perusahaan dan Umur Perusahaan berpengaruh secara simultan (bersamasama) berpengaruh terhadap Audit Report Lag. Hal ini dibuktikan dengan hasil pengujian hipotesis secara simultan, bahwa nilai dari signifikan sebesar 0.012 yang lebih kecil dari derajat kebebasan $(\alpha) 0.05$, yang berarti H4 diterima. 


\section{PENGARUH UKURAN KAP, UKURAN PERUSAHAAN DAN UMUR PERUSAHAAN TERHADAPAUDIT REPORT LAG PADA PERUSAHAAN MANUFAKTUR YANG TERDAFTAR DI BEI TAHUN 2016-2018}

\section{REFERENSI}

Arifuddin, dkk. 2017. Company Size, Profitability, And Auditor Opinion Influence To Audit Report Lag On Registered Manufacturing Company In Indonesia Stock Exchange. International Journal Of Applied Business And Economic Research. Vol 15/No 19/2017. Hlm : 353-367.

Agoes, Sukrisno. 2016. Auditing. Jakarta : Salemba Empat

Azizah, Nur Dan Ratih Kumalasari. 2014. Pengaruh Profitabilitas, Rasio Hutang, Ukuran Perusahaan Dan Jenis Perusahaan Terhadap Audit Report Lag. Hlm : 130-142.

Fodio, Musa Inuwa, dkk. 2015. IFRS Adoption, Firm Traits And Audit Timeliness: Evidence From Nigeria. Acta Universitatis Danubius. Vol 11/No 3/2015. Hlm : 106-119.

Franedya, Roy. Tak Sampaikan Lapkeu 2017 Auditan, BEI Suspensi 10 Saham. www.cnbcindonesia.com (2 Juli 2018)

Giyanto, Sinta Cahyaningrum Dan Abdul Rohman. 2018. Analisis Pengaruh Ukuran Kap, Tenure Kap Terhadap Audit Report Lag (ARL) Dengan Kap Spesialisasi Industri Sebagai Variabel Moderasi. Diponegoro Journal Of Accounting. Vol 7/No 4/2018. Hlm : 1-14

Ikatan Akuntan Indonesia. 2018. Draf Eksposur Kerangka Konseptual Pelaporan Keuangan. Jakarta: Ikatan Akuntan Indonesia.

Ikhsan, Arfan., dkk. 2018. Auditing Pemeriksaan Akuntansi. Medan : Madenatera

Ikhsan, Arfan., dkk. 2018. Teori Akuntansi. Medan : Madenatera

Iskandar, Meylisa Januar dan Estralita Trisnawati. 2010. Faktor-Faktor Yang Mempengaruhi Audit Report Lag Pada Perusahaan Yang Terdaftar Di Bursa Efek Indonesia. Jurnal Bisnis Dan Akuntansi. Vol 12/No 3/2010. Hlm : 175-186.

Kuncoro, Mudjarab. 2009. Metode Riset untuk Bisnis \& Ekonomi Edisi 3. PT. Gelora Aksara Pratama.

Lianto, Novice Dan Budi Hartono Kusuma. 2010. Faktor-Faktor Yang Berpengaruh Terhadap Audit Report Lag. Jurnal Bisnis Dan Akuntansi. Vol 12/No. 2/2010. Hlm : 98 - 107

Mazkiyani, Nur. 2017 . Audit Report Lag Of Listed Companies In Indonesia Stock Exchange. Jurnal Aplikasi Bisnis. Vol 17/No 1/2017. Hlm : 77-95

Melani, Agustina. Awal Juli 2019, BEI Suspensi 10 Saham Emiten Ini. www.liputan6.com. (1 Juli 2019)

Panjaitan, Ingrid. 2017. Pengaruh Ukuran KAP, Return on Assets dan Loan to Deposit Ratio terhadap Audit Report Lag. Jurnal Aplikasi Manajemen, Ekonomi dan Bisnis. Vol 1/No 2/2017. Hlm : 36-50.

Prabandari, Jeane Deart Meity dan Rustiana. 2007. Beberapa Faktor Yang Berdampak Pada Perbedaan Audit Delay (Studi Empiris Pada Perusahaan-Perusahaan Keuangan Yang Terdaftar Di BEJ). Kinerja. Vol 11/No 1/2007. Hlm : 27-39.

Sastrawan, I Putu Dan Made Yenni Latrini. 2016. Pengaruh Profitabilitas, Solvabilitas, Dan Ukuran Perusahaan Terhadap Audit Report Lag Pada Perusahaan Manufaktur. E-Jurnal Akuntansi Universitas Udayana. Vol 17/No 1/2016. Hlm : 311-337.

Sitorus Novita Jayanti Dan Aloysia Yanti Ardiati. 2017. Pengaruh Standar Akuntansi Keuangan Indonesia Baru, Ukuran Kantor Akuntan Publik, Ukuran Perusahaan Dan Umur Perusahaan Terhadap Audit Report Lag. Modus. Vol. 29/2017. Hlm : 139-156.

Sugianto, Danang. 17 Saham Disuspensi Sekaligus, dari BTEL hingga ENRG. http://finace.detik.com (3 Juli 2019)

Sumartini, Ni Komang Ari Dan Ni Luh Sari Widhiyani. 2014. Pengaruh Opini Audit, Solvabilitas, Ukuran Kap Dan Laba Rugi Pada Audit Report Lag. E-Jurnal Akuntansi Universitas Udayana. Hlm : 392-409.

Ustman 2020. The Effect Of Solvency, Firm Size, Age Companies On Audit Report Lag In Indonesian Company. Research Journal Of Finance And Accounting. Vol.11/No.2/2020. Hlm : 17-22

Widiastuti, Ika Destriana dan Andi Kartika. 2018. Ukuran Perusahaan, Profitabilitas, Umur Perusahaan, Solvabilitas Dan Ukuran Kap Terhadap Audit Report Lag. Dinamika Akuntansi, Keuangan Dan Perbankan. Vol. 7/No. 1/2018. Hal : 20 - 34. 